\title{
The Relationship between Iranian English Language Learners' Learning Styles and Strategies
}

\author{
Zahra Zohoorian Vahid Baghban \\ Department of languages, Islamic Azad University, Mashhad branch, Iran \\ Email: Marjan.zohoorian@yahoo.com
}

\begin{abstract}
The present study aimed at finding the degree of relationship between Iranian learners' learning styles and their preferences in using specific language learning strategies. The study was conducted on female EFL learners at the Iran Language Institute (ILI) in advanced levels and also university students of English teaching at Azad University of Mashhad. By employing such instrumentation as the Strategy Inventory for Language Learning (SILL) and also Language Learning Style (LLS) questionnaire the investigator found a significant relationship between learning styles and learning strategies used by the learners. Based on the results it can be concluded that learners scoring higher on the SILL performed better on the LLS, leading to the conclusion that SILL has a significant impact on LLS. Based on the factor analysis it was found out that cognitive, metacognitive, and most of all affective strategies showed a great correlation with the auditory style of learning. Also, metacognitive and most of all memory and social strategies showed a great correlation with the kinesthetic style.
\end{abstract}

Index Terms — language learning, learning styles, learning strategies, good learners, individual differences

\section{INTRODUCTION}

Unlike the primeval teaching methodologies, today's methodologies have shifted their stress from the language and teachers to learners and their learning. In traditional classrooms learners typically did not learn how to become better learners on their own. But in modern views that are learner-centred the attempt is to let learners know their own learning style and choose strategies which are more appropriate to them.

Thus, to provide a more efficient teaching situation several concerns about the language learners and their relation with the content, method, and media of the instruction are to be accounted for. In other words, learners must be encouraged and expected to play a more active role in their learning. Several individual characteristics influence learning and performance in an academic setting. Littlewood (1995) argues that although there is one unique way of language development, learners take different pathways due to the individual differences. One of the individual differences includes learning styles.

Furthermore, according to Stern (1992), learning strategy concept is very much dependent on the proposal of learners' cognisant engagement in classroom activities in order to achieve pre-specified goals. Stern defines learning strategies as broadly conceived intentional directions and learning techniques. Language learners use language learning strategies either consciously or unconsciously for information processing and task performance. However, many researchers have described successful language learners and their strategies. One major finding among them is that successful language learners in general use more and better learning strategies than do poorer learners. This result has appeared consistently in L2 learning strategy studies (Stern 1975; Rubin 1975; Hosenfeld 1977; Naiman et al., 1978). These early researchers tended to make lists of strategies presumed to be essential for all good language learners.

\section{REVIEW OF LITERATURE}

\section{A. Language Learning Styles and Their Assessment}

Ever since 1970s many factors are identified which account for the learning differences. Research on learning styles is based on the assumption that learners receive information through their senses and prefer some senses over others in specific situations (O’Brien 1989, Oxford and Ehrman, 1988). Usually, students learn more effectively when they learn through their own initiatives. Style refers to individual preferences, and closely relates to the personality and intellectual functioning. Thus, students preferentially take in and process information in different ways: by seeing and hearing, reflecting and acting, reasoning logically and intuitively, and analyzing and visualizing. Accordingly, learning style is a persistent inborn concept which unifies such elements like cognitive, affective, and behavioural (Oxford et al. 1988). According to Shipman and Shipman (1985), at least twenty dimensions of learning styles have been identified. In the following paragraph some of the dimensions will be briefly reviewed.

One of the most widely researched dimensions of learning style is "field independence vs. dependence". Field 
independent learners easily separate key details from a complex or confusing background, while their field dependent peers have trouble doing this (Hansen \& Stansfield 1981; Chapelle \& Roberts, 1986). The Myers-Briggs Type indicator (Myers \& McCaulley 1985) contributes four more dimensions to learning style including extraversion vs. introversion, sensing vs. intuition, thinking vs. feeling, and judging vs. perceiving. Kolb's 1984 (cited in Marlow \& Shaw, 1999) category divides learning styles into four categories of divergers, assimilators, convergers, and accommodators. Though many learning-style models have emerged, for non-native speakers of English, Reid's (1984) Perceptual Learning Style Preference Questionnaire (PLSPQ), O'Brien's (1990) Learning Channel Preference Checklist and Oxford's (1993) Style Analysis Survey are among the better known of the learning style assessment instruments in the ESL/EFL field (Wintergersta et al, 2001). Thus, the learning style taxonomy referred to in the present study is Ried's (1987) in which he encompasses the following categories: Visual learning or the tendency to learn via visual channel, Auditory learning or the tendency to learn via auditory sense, Kinesthetic learning or the tendency to learn via body movements, Individual or group learning or the tendency to learn better individually or within the group.

Kelly (2010) mentions three major types of learning styles with their definitions. As she mentions a learner with a visual learning style "think[s] in terms of pictures"; thus, they learn best through visual or handouts. Auditory learners can learn best if they listen. So, for such students lectures and classroom discussions can work best. Moreover this type of learners may need to read the written texts aloud in order to learn. The last group of learners are kinaesthetic or tactile learners who can learn best when they touch, feel, or experience. So, the best way of learning for them is through hands-on experiments.

However, another category is introduced by Cassidy, et al (2010) which includes four types of styles as visual, auditory, tactile-kinesthetic, and kinesthetic. In their categorization they distinguish a learner who has tactile-kinesthetic learning style from a kinesthetic one in that the former likes to write things down and incorporate his/her fine motor skills. Moreover, they like taking notes while listening and at the same time keeping their hands busy, while the latter needs to involve his/her body in the learning process. So such learners prefer doing to watching or listening in order to gain understanding. Learners with Kinetshetic style prefer activities which demand their full involvement such as doing projects, acting dramas, or designing.

Discussing the importance of learning styles, Hickcox (1995) refers to two reasons for the significance of assessing learning styles particularly in higher education contexts and for adult learners. Firstly, he believes that researchers propose that by assessing learning styles, teachers' awareness regarding learners' preferences will be broadened and could be used in to simulate students' learning more effectively. Secondly, he mentions that learners' self-knowledge will be increased if after the administration of a learning style inventory teachers explain how students can use their knowledge about their own learning styles.

\section{B. Language Learning Strategy and the Assessment}

Research into language learning strategies began in the 1960s. Particularly, cognitive psychology developments influenced the research done on language learning strategies to a large extent. From early examples of research such as the studies carried out by Rubin (1975) and Stern (1975), to taxonomies of strategies which were drawn up by Oxford (1990b), to theories of language acquisition which include strategies (O'Malley \& Chamot, 1990), a great deal of work has been done in attempting to identify what might be good language learning strategies, and in trying to establish a relationship between these and successful language learning.

Richards and Platt (2008) define learning strategies as "intentional behaviours and thoughts used by learners during learning so as to better help them understand, learn, or remember new information". Faerch \& Kasper (1983) stress that a learning strategy is the effort made by the learners in order to build up their linguistic and sociolinguistic competence. For Cohen (1998), strategies are the conscious moves made by learners either in using or learning a target language. Being unobservable and mentalistic processes, special assessment methods such as oral interviews, written questionnaires, observation, verbal report, diaries and dialog journals are needed to asses. Oxford and Burry (1995)mention that different scholars of the field proposed different inventories:

Bialystok (1981) used a 12-item, structured, untitled rating scale for strategy assessment. The scale asked questions about the extent to which strategies were used for both oral and written tasks both in communicative settings and in formal classroom settings. However, reliability and validity data were absent for this instrument.

Politzer (1983) published a strategy scale including 51 items divided into three groups: general behaviours, classroom behaviours, and interactions outside of the class. Politzer and McGroaty (1985) used a somewhat similar Behaviour Questionnaire containing 66 items divided into three groups: individual study behaviours, classroom behaviours, and interactions outside of class. However, reliability was marginally acceptable $(.51, .61$, and .63) for their scale. According to Oxford and Burry (1995) one of the most prevalent ways to assess the use of language learning strategies is to use a summative rating scale, popularly known as a questionnaire, an inventory, or a survey.

\section{THE PRESENT STUDY}

\section{A. Methodology}

\section{Purpose of the study}

The present study attempted to seek whether there is any significant correlation between the learners' learning styles 
and the use of specific strategies in language learning. That is, it sought to find if there is a relationship between the learner's preferences in learning a language (visual, auditory, and kinetic) which is proposed by Reid (1987) and the strategies used by learners which were mainly based on Oxford (1990 a) that was enriched by ideas from Green and Oxford (1995), and Khaldie (2000) which consisted of strategies including memory, cognitive, compensation, metacognitive, affective, and social.

\section{Participants}

The total number of the sampled population in the present study included 200 female Iranian college students of ages between 17 and 22 studying English Teaching at Mashhad Azad University and also English language learners learning English at the Iran Language Institute (ILI) in advanced levels. Based on the subjects' scores on the test of Michigan, the number reduced to 120 since only those who got the score above 75 were selected as proficient.

\section{B. Instruments}

\section{Michigan State University English Language Exam}

It consisted of 100 items, 40 items on structure, 40 items on vocabulary, and 20 items on reading comprehension.

\section{The Learning Styles Inventory (LSI)}

Reid's questionnaire consisted of 30 items. In the form of statements and the items were divided into five major categories including: group (Qs: 3, 4, 5, 21, 23), individual (Qs: 13, 18, 27, 28, 30), visual (Qs: 6, 10, 12, 24, 29), auditory (Qs: 1, 7, 9, 17, 20), and tactile/Kinesthetic (Qs: 2, 8, 11, 14, 15, 16, 19, 22, 25, 26)

\section{The Language Learning Strategy Inventory}

A 99-item questionnaire based on Oxford's 80-item Strategy Inventory for Language Learning (SILL) version 8, enriched with ideas taken from Green and Oxford (1995), and Khaldie (2000), all of which were ultimately based on Oxford's (1990a) was used. The questionnaire included memory strategies, cognitive strategies, compensation strategies, metacognitive strategies, affective strategies, and social strategies.

\section{Data Collection and Scoring}

The data collection procedure was carried out in two sessions. The first session a Michigan proficiency test was administered to determine the levels of proficiency of the participants to ensure homogeneity on the part of language proficiency. In the second session the subjects were given the two questionnaires on styles and strategies. The first was Reid's (1987) learning style questionnaire. The other instrument was Strategy Inventory for Language Learning taken from Oxford's (80-item strategy inventory for language learning (SILL), enriched by ideas from Green and Oxford (1995), and Khaldie (2000), which was ultimately based on Oxford's (1990a) classification of language learning strategies.

\section{Data Analysis}

A one-way ANOVA was run to investigate the effect of styles on strategy uses. Also a factor analysis through the varimax rotation method was carried out to investigate the underlying constructs of the components of LSI and LLS questionnaires.

\section{RESULTS}

In order to find out if there is any relationship between the Iranian EFL learners' learning styles and their use of specific learning strategies, it was first necessary to convert the LSI scores to nominal ones. Based on the $33^{\text {rd }}$ and $66^{\text {th }}$ percentile ranks, the subjects were divided into three groups based on the SIL scores. Those scoring 45 and above formed the high group. Those scoring 41 and below formed the low group and the rest constituted the mid group.

A one-way ANOVA was run to investigate the effect of the SIL on LLS. The F observed value, 134.13 at 2 and 717 degrees of freedom was much greater than the critical F-value, i.e. 3.01 (table 1). Thus, the conclusion could be drawn that the styles of learning have a significant impact on the learning strategies.

TABLE 1.

ONE-WAY ANOVA LLS BY SIL

\begin{tabular}{|l|l|l|l|l|l|}
\hline ANOVA SCORES & $\begin{array}{l}\text { Sum } \\
\text { of Squares }\end{array}$ & df & $\begin{array}{l}\text { Mean } \\
\text { Square }\end{array}$ & F & Sig. \\
\hline Between Groups & 1074.043 & 2 & 537.021 & 134.315 & .000 \\
\hline Within Groups & 2866.733 & 717 & 3.998 & & \\
\hline Total & 3940.775 & 719 & & & \\
\hline \hline
\end{tabular}

Furthermore, the results of the post-hoc Scheffe's tests (table.2) indicate that:

a. The high group $($ mean $=14.11)$ performed better than the low group $($ mean $=11.12)$,

b. The high group $($ mean $=14.11)$ performed better than the mid group $($ mean $=12.78)$,

c. The mid group $($ mean $=12.78)$ performed better than the low group $($ mean $=11.12)$. 
TABLE 2.

POST-HOC SCHEFFE'S TESTS

\begin{tabular}{|c|c|c|c|c|c|c|}
\hline \multicolumn{7}{|c|}{$\begin{array}{l}\text { Multiple Comparisons } \\
\text { Dependent Variable: SCORES Scheffe }\end{array}$} \\
\hline \multirow{2}{*}{ (I) SILCODE } & \multirow{2}{*}{ (J) SILCODE } & \multirow{2}{*}{ Mean Difference (I-J) } & \multirow{2}{*}{ Std. Error } & \multirow{2}{*}{ Sig. } & \multicolumn{2}{|c|}{ 95\% Confidence Interval } \\
\hline & & & & & Lower Bound & Upper Bound \\
\hline \multirow{2}{*}{ High } & mid & $1.3299(*)$ & .18253 & .000 & .8822 & 1.7776 \\
\hline & low & $2.9858(*)$ & .18253 & .000 & 2.5381 & 3.4335 \\
\hline mid & high & $-1.3299(*)$ & .18253 & .000 & -1.7776 & -.8822 \\
\hline
\end{tabular}

Based on these results it could be concluded that those scoring higher on the SIL performed better on the LLS, leading to the conclusion that SIL has a significant impact on LLS. Later factor analysis will be another proof for this hypothesis.

In addition, a factor analysis through the varimax rotation method was carried out to investigate the underlying constructs of the components of the Michigan test, and LSI and LLS questionnaires. The SPSS extracted four factors that are displayed in Table 3, which account for 58.02 percent of the total variance.

TABLE 3.

TOTAL VARIANCE EXPLAINED

\begin{tabular}{|c|c|c|c|c|c|c|c|c|c|}
\hline \multicolumn{10}{|c|}{ Total Variance Explained } \\
\hline \multirow{2}{*}{ Component } & \multicolumn{3}{|c|}{ Initial Eigen values } & \multicolumn{3}{|c|}{ Extraction Sums of Squared Loadings } & \multicolumn{3}{|c|}{ Rotation Sums of Squared Loadings } \\
\hline & Total & $\%$ of Variance & Cumulative \% & Total & $\%$ of Variance & Cumulative $\%$ & Total & $\%$ of Variance & Cumulative \% \\
\hline 1 & 2.759 & 25.086 & 25.086 & 2.759 & 25.086 & 25.086 & 2.214 & 20.131 & 20.131 \\
\hline 2 & 1.407 & 12.791 & 37.877 & 1.407 & 12.791 & 37.877 & 1.785 & 16.223 & 36.354 \\
\hline 3 & 1.178 & 10.706 & 48.582 & 1.178 & 10.706 & 48.582 & 1.208 & 10.978 & 47.332 \\
\hline 4 & 1.037 & 9.430 & 58.012 & 1.037 & 9.430 & 58.012 & 1.175 & 10.680 & 58.012 \\
\hline 5 & .985 & 8.957 & 66.969 & & & & & & \\
\hline 6 & .875 & 7.954 & 74.923 & & & & & & \\
\hline 7 & .731 & 6.650 & 81.573 & & & & & & \\
\hline 8 & .677 & 6.158 & 87.731 & & & & & & \\
\hline 9 & .575 & 5.228 & 92.958 & & & & & & \\
\hline 10 & .451 & 4.096 & 97.054 & & & & & & \\
\hline 11 & .324 & 2.946 & 100.000 & & & & & & \\
\hline
\end{tabular}

Factor loadings are displayed in Table 4. Four sections of the LLS, i.e. social, compensation, metacognitive, and memory load on the first factor together with the kinesthetic section of the LSI. The affective and the cognitive sections of the LLS together with the auditory section of the LSI load on the second factor. It can be concluded that except for the first four factors mentioned which belong to the LLS, the LSI and Michigan have not shown stable underlying constructs, because four sections of the language learning strategies load on the first factor, i.e. social, compensatory, metacognitive and memory, while affective and cognitive load on the second factor. While three sections of the learning styles load on three different factors. That is, kinesthetic on the first, auditory on the second, and the visual on the third factors. 
TABLE 4.

FACTOR EXTRACTION

\begin{tabular}{|l|l|l|l|l|}
\hline Rotated Component Matrix(a) \\
\hline & \multicolumn{3}{|l|}{ Component } \\
\cline { 2 - 5 } & $\mathbf{1}$ & $\mathbf{2}$ & $\mathbf{3}$ & $\mathbf{4}$ \\
\hline SOCIAL & .798 & & & \\
\hline COMPENS & .722 & & & \\
\hline METACOG & .559 & .406 & & \\
\hline MEMORY & .532 & .434 & & .361 \\
\hline KINEST & .465 & & & .365 \\
\hline AFFECT & & .814 & & \\
\hline AUDIT & & .655 & & \\
\hline COGNIT & .473 & .569 & & \\
\hline VISUAL & & & .793 & \\
\hline VOCSTR & & & -.651 & \\
\hline READING & & & .867 \\
\hline Rotation Method: Varimax with Kaiser \\
Normalization.
\end{tabular}

Finally, Table 5 displays the correlation matrix of the variables investigated in this study. The coefficients with one asterisk are significant at.05 level, and those with two asterisks are significant at .001 level. The critical value of $\mathrm{r}$ at 118 degrees of freedom is 0.19 . 
TABLE 5.

CORRELATION MATRIX

\begin{tabular}{|c|c|c|c|c|c|c|c|c|c|c|}
\hline \multirow{2}{*}{ Correlations } & & & & & & & & & & \\
\hline & & visual & audit & kinest & memory & cognit & compens & metacog & affect & social \\
\hline \multirow{3}{*}{ visual } & Pearson Correlation & 1 & .036 & .084 & -.112 & -.008 & .138 & -.116 & -.060 & -.049 \\
\hline & Sig. (2-tailed) & . & .699 & .364 & .224 & .932 & .133 & .206 & .518 & .598 \\
\hline & $\mathbf{N}$ & 120 & 120 & 120 & 120 & 120 & 120 & 120 & 120 & 120 \\
\hline \multirow{3}{*}{ audit } & Pearson Correlation & .036 & 1 & .101 & .117 & $.221(*)$ & .042 & $.202(*)$ & $.307(* *)$ & .084 \\
\hline & Sig. (2-tailed) & .699 & . & .274 & .202 & .015 & .648 & .027 & .001 & .361 \\
\hline & $\mathbf{N}$ & 120 & 120 & 120 & 120 & 120 & 120 & 120 & 120 & 120 \\
\hline \multirow{3}{*}{ kinest } & Pearson Correlation & .084 & .101 & 1 & $.253(* *)$ & .130 & .124 & $.227(*)$ & .034 & $.364(* *)$ \\
\hline & Sig. (2-tailed) & .364 & .274 & . & .005 & .156 & .177 & .013 & .711 & .000 \\
\hline & $\mathbf{N}$ & 120 & 120 & 120 & 120 & 120 & 120 & 120 & 120 & 120 \\
\hline \multirow{3}{*}{ memo } & Pearson Correlation & -.112 & .117 & $.253(* *)$ & 1 & $.557(* *)$ & $.269(* *)$ & $.417(* *)$ & $.254(* *)$ & $.340(* *)$ \\
\hline & Sig. (2-tailed) & .224 & .202 & .005 & . & .000 & .003 & .000 & .005 & .000 \\
\hline & $\mathbf{N}$ & 120 & 120 & 120 & 120 & 120 & 120 & 120 & 120 & 120 \\
\hline \multirow{3}{*}{ cognit } & Pearson Correlation & -.008 & $.221(*)$ & .130 & $.557(* *)$ & 1 & .154 & $.398(* *)$ & $.295(* *)$ & $.396(* *)$ \\
\hline & Sig. (2-tailed) & .932 & .015 & .156 & .000 & . & .093 & .000 & .001 & .000 \\
\hline & $\mathbf{N}$ & 120 & 120 & 120 & 120 & 120 & 120 & 120 & 120 & 120 \\
\hline \multirow{3}{*}{ compe } & Pearson Correlation & .138 & .042 & .124 & $.269(* *)$ & .154 & 1 & $.267(* *)$ & -.011 & $.350(* *)$ \\
\hline & Sig. (2-tailed) & .133 & .648 & .177 & .003 & .093 & . & .003 & .907 & .000 \\
\hline & $\mathbf{N}$ & 120 & 120 & 120 & 120 & 120 & 120 & 120 & 120 & 120 \\
\hline \multirow{3}{*}{ metac } & Pearson Correlation & -.116 & $.202(*)$ & $.227(*)$ & $.417(* *)$ & $.398(* *)$ & $.267(* *)$ & 1 & $.233(*)$ & $.350(* *)$ \\
\hline & Sig. (2-tailed) & .206 & .027 & .013 & .000 & .000 & .003 & . & .010 & .000 \\
\hline & $\mathbf{N}$ & 120 & 120 & 120 & 120 & 120 & 120 & 120 & 120 & 120 \\
\hline \multirow{3}{*}{ affect } & Pearson Correlation & -.060 & $.307(* *)$ & .034 & $.254(* *)$ & $.295(* *)$ & -.011 & $.233(*)$ & 1 & -.087 \\
\hline & Sig. (2-tailed) & .518 & .001 & .711 & .005 & .001 & .907 & .010 & . & .345 \\
\hline & $\mathbf{N}$ & 120 & 120 & 120 & 120 & 120 & 120 & 120 & 120 & 120 \\
\hline \multirow{3}{*}{ social } & Pearson Correlation & -.049 & .084 & $.364(* *)$ & $.340(* *)$ & $.396(* *)$ & $.350(* *)$ & $.350(* *)$ & -.087 & 1 \\
\hline & Sig. (2-tailed) & .598 & .361 & .000 & .000 & .000 & .000 & .000 & .345 & . \\
\hline & $\mathbf{N}$ & 120 & 120 & 120 & 120 & 120 & 120 & 120 & 120 & 120 \\
\hline
\end{tabular}

\section{DisCUSSION AND CONCLUSION}

Cognitive, metacognitive, and most of all affective strategies showed a great correlation with the auditory style of learning. Also, metacognitive and most of all memory and social strategies showed a great correlation with the kinesthetic style. Visual learning style did not show any correlation with the other factors. Moreover, it is possible to put the strategies in a hierarchy of importance by placing memory strategies together with metacognitive strategies at the top. The next level includes social, affective, and compensation strategies. However, by finding out more about the good language learners' strategy preferences, teachers can teach the poor ones the strategies that the successful language learners use. Moreover, by finding out about learners' learning styles as an inherent capacity both teachers and learners may benefit by gaining more knowledge about the ways of learning that better match their style and preferences.

\section{REFERENCES}

[1] Cassidy, C., Kreitner, B, \& Kreitner, R. (2010). Supervision: setting people up for success. Ohio: South-Western Cengage Learning. 
[2] Chapelle, C., \& Roberts, C. (1986). Ambiguity tolerance and field independence as predictors in English as a second language. Language Learning, 36.1, 27-45.

[3] Cohen, A. D. (1998). Strategies in learning and using a second language: applied linguistics and language study. New York: Addison Wesley Longman.

[4] Faerch, C., \& Kasper, G. (1983). Plans and strategies in foreign language communication. In C. Faerch, and G. Kasper. (Eds.), strategies of interlanguage communication. London: Longman.

[5] Green, J. M., \& Oxford, R. L. (1995). A closer look at learning strategies, L2 proficiency, and gender. TESOL Quarterly, 29.2, 261-297.

[6] Hansen, J. \& Stansfield, C. W. (1981). The relationship of field dependent-independent cognitive styles to foreign language achievement. Language Learning, 31.3, 349-67.

[7] Hickcox, 1. K. (1995). Learning styles: a survey of adult learning style. In Sims, R.R., \& Sims, S. J. (Eds). The importance of learning styles: understanding the implications for learning, course design, and education. Connecticut: Greenwood Press. Pp 25-49.

[8] Hosenfeld, C. (1977). A preliminary investigation of the reading strategies of successful and non-successful second language learners. System, 5.1, 110-123.

[9] Kelly, M. (2010). The everything new teacher book: a survival guide for the first year and beyond. Massachusetts, Adams Media.

[10] Khaldie, S. A. (2000). Learning strategies and writing processes of proficient vs. less proficient learners of Arabic. Foreign Language Annals, 33.5, 522-533.

[11] Littlewood, W. (1995). Foreign and second language learning; language learning acquisition and its implications for the classroom. Cambridge: Cambridge University Press.

[12] Marlow, N., \& Shaw, G. (1999). The role of student learning styles, gender, attitudes and perceptions on information and communication technology assisted learning. Computers \& Education, 33, 223-234.

[13] Myers, LB., \& McCaulley, M.H. (1985). Manual: A guide to the development and use of the Myers-Briggs Type Indicator. Palo Alto, CA: Consulting Psychologists Press.

[14] Naiman, N., Frohlich, M., Stern, H. H., \& Todesco, A. (1978). The good second language learner. TESL Talk, 6.1, 58-75.

[15] O'Brien, L. (1989). Learning styles: make the student aware. National Association of Secondary School Principals' Bulletin, 73 , $85-89$.

[16] O'Malley, J.M., \& Chamot, A.U. (1990). Learning strategies in second language acquisition. Cambridge: Cambridge University Press.

[17] Oxford, R. L., \& Ehrman, M. (1988). Psychological type and adult language learning strategies: A pilot study. Journal of psychological type, 16, 22-32.

[18] Oxford, R. L., Nyikos, M., \& Ehrman, M. (1988). Vive la difference? Reflections on sex differences in use of language learning strategies. Foreign Language Annals, 21.4, 321-329.

[19] Oxford, R.L. (1990a). Language learning strategies and beyond: A look at strategies in the context of styles. In S.S. Magnan (Ed.), shifting the instructional focus to the learner. Middlebury, VT: Northeast Conference on the Teaching of Foreign Languages. 35-55.

[20] Oxford, R.L. (1990b). Language learning strategies: What every teacher should know. Boston: Heinle \& Heinle.

[21] Oxford, R. L. and Burry, J. L. A. (1995). Assessing the use of language learning strategies worldwide with the ESL/EFL version of the strategy inventory for language learning (SILL). System, 23.1, 1-23.

[22] Politzer, R. (1983). An exploratory study of self-reported language learning behaviors and their relation to achievement. Studies in Second Language Acquisition, 6, 54-65.

[23] Politzer, R., \& McGroaty, M. (1985). An exploratory study of learning behaviours and their relationship to gains in linguistic and communicative competence. TESOL Quarterly, 19.2, 103- 124.

[24] Reid, M. J. (1987). The learning style preferences of ESL students. TESOL Quarterly, 21.1, 87-95.

[25] Richards, J., \&, Platt, J., (2008). Longman Dictionary of Language Teaching and Applied Linguistics. Essex: Longman.

[26] Rubin, J. (1975). What the "good language learner" can teach us. TESOL Quarterly, 9.1, 41- 51.

[27] Shipman, S., \& Shipman, V. (1985). Cognitive styles: Some conceptual, methodological, and applied issues. In E. Gordon (Ed.), Review of research in education, Washington, DC: American Educational Research Association, 229-91.

[28] Stern, H. H. (1975). What can we learn from the good language learner? The Canadian Modern Language Review, 31, 304-318.

[29] Stern, H. H. (1992). Issues and options in language teaching. Oxford: Oxford University Press.

[30] Wintergersta, C. A., DeCapuab, A., \& Itzenc, C. R. (2001). The construct validity of one learning styles instrument. System $29.3,385-403$

Zahra Zohoorian Vahid Baghban received her BA in English teaching from Islamic Azad University of Mashhad, Iran and her MA in Language teaching from Islamic Azad University, research and science branch, Tehran, Iran. She is currently a PhD candi date at the school of languages, University science Malaysia (USM).

She has been teaching English for ten years at institution and university level. She currently holds a fellowship from USM. She is also a faculty member at Islamic Azad university of Mashhad, Iran. She has three textbook publications with co-authors for ESP/EAP courses. Her research interests include ESP/EAP, materials development, syllabus design, learners motivation, learning styles, and learning strategies. 